DOI: https://doi.org/10.32839/2304-5809/2021-11-99-32

UDC $1+14 / 141+165$

Yarmolitska Nataliia ${ }^{1}$, Turenko Vitalii ${ }^{2}$

Taras Shevchenko National University of Kyiv

\title{
RESEARCH OF PHILOSOPHICAL PROBLEMS OF BIOLOGY IN THE KYIV WORLDVIEW AND EPISTEMOLOGICAL PHILOSOPHICAL SCHOOL IN THE SECOND HALF OF THE XX CENTURY
}

Summary. The article is devoted to the study of the phenomenon of the the Kyiv worldview and epistemological philosophical school within which the research of philosophical problems of biology in the second half of the XX century took place. The history of the Kyiv School of Philosophy of Biology was reconstructed, the directions and problems of scientific research carried out in Soviet Ukraine in the second half of the XX century were analyzed by representatives of the Ukrainian scientific community from the Institute of Philosophy of the USSR Academy of Sciences and Kyiv University. It is established that scientists of the Kyiv School of Philosophy of Biology, on the basis of materialist dialectics, studied evolutionary methods in biology and general methods of natural science, paid attention to the correct understanding of specific features of biological methods of living nature research and correlation with methods of other sciences. in science. This study is aimed at popularizing and disseminating the achievements of the Ukrainian philosophical heritage, their modern scientific vision for further modernization of scientific research and training of specialists in the fields of philosophy, social sciences, humanities and natural sciences.

Keywords: philosophical problems of biology, the Kyiv worldview and epistemological philosophical school, Kyiv school of philosophy of biology, Soviet era.

Ярмоліцька Н.В., Туренко В.Е. Київський національний університет імені Тараса Шевченка

\section{ДОСЛІДЖЕННЯ ФІЛОСОФСЬКИХ ПРОБЛЕМ БІОЛОГІї В КИЇВСЬКІЙ СВІТОГЛЯДНО-ГНОСЕОЛОГІЧНІЙ ШКОЛІ В ДРУГІЙ ПОЛОВИНІ ХХ СТОЛІТТЯ}

Анотація. Стаття присвячена вивченню феномену Київської світоглядно-гносеологічної школи в межax якої відбувались дослідження філософських проблем біології в другій половині ХХ століття. Здійснено реконструкцію історії розвитку Київської школи фрілософії біології, проаналізовано напрями та проблематику наукових досліджень, що здійснювались в радянській Україні другої половини ХХ століття, представниками українського наукового співтовариства з числа фахівщів Інституту фрілософії АН УРСР та науково-викладацького складу Київського університету. Встановлено, що науковці Київської школи фрілософії біології, на основі матеріалістичної діалектики, досліджували еволюційні методи у біології й загальні методи природознавства, звертали увагу на правильність розуміння специфічних особливостей біологічних методів дослідження живої природи та співвідношення з методами інших наук, підіймали питання про єдність теорії і методу в науці. Показано, що серед наукових методів київські науковці виокремлювали історико-біологічний метод, який найбільш повно конкретизував загальнобіологічну теорію розвитку, е основним і провідним в біологічних дослідженнях, i одним із істотних засобів подальшого розвитку біології. Також, важливого значення набували дослідження проблеми становлення системноструктурного методу в біології. Саме системно-структурний метод вважався одним із загальнонаукових методів, який успішно застосовувався як в природничих так і соціальних науках. У біології системноструктурний метод, раніше ніж в інших науках виділився як загальнонауковий, а його застосування в системно-структурному підході до дослідження живого було пов'язано із розумінням того, що життя - це процес, а організм - складна і своерідна взаємодія систем та рівнів організації. Паралельно, київськими науковцями здійснювались дослідження таких понять у природознавстві та фрiлософіï, як «цілі», «цільове відношення», «біологічне», «соціальне», а також проблема «зведення» у філософії та біології. Дане дослідження спрямоване на популяризацію та поширення здобутків української фрілософської спадшини, їх сучасного наукового бачення для подальшої модернізації наукових досліджень та підготовки фрахівців у галузях фрілософії, суспільствознавчих, гуманітарних та природничих наук.

Ключові слова: фрілософські проблеми біології, Київська світоглядно-гносеологічна школа, Київська школа фрілософії біології, радянська доба,

Tormulation of the problem. Any scientific work is aimed at the future, it is aimed at reflecting the thoughts, thoughts, arguments that the scientist comes to in the process of their research. In this spirit, research on the ideas of philosophical understanding of biology in the mid-60s of the XXth century. in the circle of the Ukrainian community of scientists. It was a joint work of scientists of the Kyiv Order of Lenin and Order of the October
Revolution T.G. Shevchenko State University and scientists of the G. Skovoroda Institute of Philosophy of AS Ukrainian SSR, who formed the core of the powerful Kyiv School of Philosophy of Biology. Ukrainian scientists put forward new fundamental ideas that developed modern philosophical ideas about the problems of life, studied the ideological and ethical problems of biology, focused on philosophical problems of certain biological disciplines, 
such as philosophical problems of evolutionary theory, philosophical problems of molecular biology, genetics and others. All these searches and transformations of approaches have been reflected in research projects, scientific articles and monographs that have been published by school scientists over the decades. However, there is a lack of systematicity, consistency and characterization of research of the Kyiv School of Philosophy of Biology, which led to the choice of this study for a more detailed coverage of issues raised by scientists of this school in the late XXth century.

Analysis of recent research and publications. Sources in the field of research on the history of philosophical thought in Ukraine and philosophical problems of science in the Soviet and post-Soviet period were the works of domestic scientists - I. Bychko, V. Gusev, N. Kostiuk, A. Loy, I. Ogorodnik, M. Popovych, M. Rusin, S. Rudenko, V. Tabachkovskyi, M. Tkachuk, O. Khoma and others. In the field of philosophy of biology should be noted the works of Kyiv scientists - T. Gardashchuk, N. Depenchuk, N. Kostiuk, M. Kyseliov, V. Krysachenko, I. Ogorodnik, T. Pikashova, M. Popov, L. Sidorenko and others. Among modern foreign publications there are works devoted to philosophical problems of natural science and in particular the philosophy of biology, including Western European and American theorists and methodologists of science - J. Bernal, M. Reuse, R. Sattler, K. Waddington and others. Scientists from the Moscow and St. Petersburg schools of philosophy of biology also work in the field of philosophy of biology, among them - I. Frolov, S. Pastushnyi, R. Karpinska, P. Anokhin, M. Dubin, O. Mamzin, A. Ugolev, Z. Sokuler, V. Lavrynenko, V. Ratnikova, S. Melyukhina, V. Tsyupko and others.

Selection of previously unsolved parts of the overall problem. It should be noted that the authors of this article have already studied the scientific achievements of scientists of the the Kyiv worldview and epistemological philosophical school of the second half of the XXth century. in the field of research of philosophical problems of natural science where the Kyiv school of philosophy of biology was briefly considered. However, they included only a small part of the scientific achievements of this school, so we think it would be appropriate to dwell in more detail on the study of the Kyiv School of Philosophy of Biology in the late XXth century.

Therefore, the aim of the article is to study the formation and development of the Kyiv School of Philosophy of Biology, which existed within the Kyiv worldview and epistemological philosophical school. Such research will contribute to the study of the history of Soviet philosophy of the second half of the XXth century, will help to deepen knowledge about Ukrainian Soviet philosophy and philosophical problems of natural science in Ukraine.

The main tasks of the study are:

- reconstruction of the Kyiv School of Philosophy of Biology;

- determination of the theoretical model of the main stages of its development in the Soviet natural and philosophical thought of the second half of the XXth century;

- explanation of key problems, description and analysis of research methodology and understand- ing of the main features of the school's existence in the Soviet period.

Presenting main material. In general, if we talk about the Kyiv School of Philosophy of Biology, it was formed and worked within the activities of the Kyiv worldview and epistemological philosophical school. It should be noted that the founder of the Kyiv School of Philosophy of Biology was a professor at the University of Kyiv - Ninel Trokhymivna Kostiuk (1926-2019). Dealing with the problems of the philosophy of biology, N. Kostiuk tried to answer the main worldview question of theoretical biology - what is the essence of living things by studying the theory of living things. The answer to this question should be sought in the methodological principle of contradiction: "the original concept, from which the general theory of living things can be developed, should reflect the basic contradiction of living things. According to the researcher, this is "self-renewal» - the unity of self-preservation and self-change» [1, p. 127].

To understand the essence of life, N. Kostiuk wrote, it is necessary to study a living organism not only in the versatility and complexity of its internal structure and functions, but also in all its connections and relations with the surrounding nature. The diversity of living things presupposes the existence of various aspects of the approach to the study of life. Along with the biological, physicochemical, cybernetic, geochemical aspect, like space, was formed not so long ago. The foundations of the biogeochemical approach to the study of life were laid by V. Vernadskyi. It was then that living things began to be studied in terms of the place it occupies in the general geological evolution of the earth's crust, as a peculiar and planetary phenomenon. Also, the development of biogeochemical ideas of $\mathrm{V}$. Vernadskyi contributed to the emergence of new scientific disciplines that explore issues that are equally interesting for geologists and chemists, and for biologists [5, p. 149-152].

N. Kostiuk's multifaceted views are impressive. Thus, the object of her research was the issues of neovitalism and mechanism. She explored the question of the difference between mechanism and vitalism, explaining that some neotomists, idealistically arguing the essence of life, set out to confuse the positions of dialectical materialism and mechanism in this matter. Considered the differences between the dialectical-materialist approach in understanding the essence of life from various varieties of neovitalism and mechanism, reviewed the views of individual representatives of these areas.

As N. Kostiuk noted, "consistently scientific perspectives in solving the problem of the essence of life can be opened only in connection with the use of dialectical-materialist methodology, which allows to reflect life as a multifaceted, multifaceted phenomenon of reality, which determines the diversity of aspects approach to it not only from the standpoint of physico-chemical laws, not only from the standpoint of functional-cybernetic, geochemical or space laws, but primarily in terms of biological laws that determine the development and existence of living things» [7, p. 151-152].

Let's analyze in more detail the scientific activity of scientists of the Kyiv School of Philosophy of Biology, consider the consistent development of 
their thoughts and the direction of research in the Soviet period.

The formation of the Kyiv School of Philosophy of Biology in the late XXth century was caused by the rapid development of natural sciences, which increasingly led to the knowledge of new branches of nature. To understand this, Soviet scientists argued, one should turn to scientific philosophy, which would help to find answers to the course of cognition, the extent to which previously accumulated knowledge could be used, and so on. Why scientific philosophy? Because it develops a general method of cognition, reveals the general principles of the relationship between the sciences. Here the movement of scientific knowledge plays a great role for the development of natural sciences, from the study of the properties of phenomena of any branch of nature to the disclosure of the structure of the material substrate, the structure of part of these phenomena. The natural sciences already have a fairly large body of material on the movement of scientific knowledge from the study of properties to the study of structure. In general, scientists of the Soviet period identified two main stages in the development of most natural sciences: the first science studies the properties of whole things that belong to this area of nature, their interaction, abstracting from the study of the material substrate that forms these things. This method is functional; in the second stage, science proceeds to study the structure of the material substrate that forms these things, and this method is the substrate. Such methods of studying phenomena mean a true revolution in their development (V. Lutay) [3, p. 17-27].

It should be noted that raising the question of the influence of materialist dialectics on the evolutionary method in biology, Kyiv scientists noted that the main issue in this issue is the study of general methods in science, which are dictated not only by considerations and needs of past dialectic history. Therefore, the problem of the history of methods has always been relevant to the science of the past, present and future. Particularly important here was "the question of the nature of the evolutionary method and its relation to materialist dialectics, the solution of which provides a basis for a correct understanding of the method and evolutionary theory of Charles Darwin and predicting the prospects of Darwinism in Michurin biology" [3, p. 147].

Thus, the dialectical-materialist concept of development, which recognizes quantitative and qualitative, gradual and abrupt changes, is a methodological basis for understanding the qualitative specifics of biological, physical, chemical movement, their material substrate, allows to reveal the difference and unity of material world and physicochemical connection of separate methods, to show their subordination, their differential value in biology, in knowledge of various displays of vital activity of an organism (V. Kolodyazhnyi) [3, p. 153] Also, attention should be paid to the correct understanding of the specific features of biological methods of studying wildlife, their relationship with the methods of other sciences, as well as the question of the unity of theory and method in science. The historical-biological method is a method of the most complete concretization of the general biological theory of development and one of the essential means of its further development. This method is the main and leading in biological research because the knowledge of biological laws is impossible without a comprehensive study of living organisms and throughout their development and the nature of the relationship of organisms with the environment (I. Svystun) [8, p. 106-110]. The study of methodological foundations in the development and improvement of some genetic concepts in biology also helps to reveal the dialectic of living nature at its various levels, both macromorphological and cellular-molecular, and the transition to experimental study of individual factors of organic evolution, improves and develops Darwinian theory of speciation (N. Goncharenko) [9, p. 121].

Problems of formation of the system-structural method in biology become the field of scientific researches of scientists of the Kyiv school of philosophy of biology. The system-structural method is one of the general scientific methods, which is successfully used in both natural and social sciences. In biology, earlier than in other sciences, objects of study began to be considered as systems. It is on the basis of biological research that the system-structural method was singled out as a general scientific one. The application of a system-structural approach to the study of living things is becoming more and more widespread, which is connected with the understanding that life is a process, and the organism is a complex and peculiar interaction of systems and levels of organization. Although the system-structural method was formed in the middle of the XX century, some features and concepts of system-structural analysis began to be used by biologists in the XVIII-XIX centuries. During this period, the leading methodological approach in biology was metaphysics, which significantly influenced the solution of the problems, but it could not prevent the distortion of the objective content of the established system-structural concepts (T. Pikashova) [12, p. 123-127].

The system of scientific methods used in biological research is divided into dialectics as a general theory of development, which provides the correct general methodological orientation and general scientific and special methods. This system of methods is characterized by complex relationships - mutual additionality, a certain dependence of methods on one, the dominant. Some trends in the cognition of living things are associated with the differentiation and integration of modern biological knowledge, its mathematization, with the use of model experiment. They are especially clearly expressed in system-structural methods, in which the general principles of dialectics applied to certain types of systems and structures are developed and concretized (S. Chernyi) [14, p. 95].

Continuing the theme of materialist dialectics, we should pay attention to the study by Kyiv scholars of the study of some issues in the dialectic of contradictions in the development of organic forms. The main focus of the research was the contradictions, the solution of which resulted in the emergence of a new biological species as a typical unity, which is another new stage in the development of the organic world. As noted by scientists, during the contradictory existence of the species, its adaptation contradicts itself, which is expressed in the form of a mismatch between adaptation and heredity, where heredity is 
essentially the same adaptation, only in terms of its form, type, as its positive, conservative side. And the point is not fatigue, that once this species ceases to be itself, but that at every moment it exists as such, because it destroys itself by its own assertion and adaptation. From which it is concluded that the way of existence and development of the species is that which denies it (V. Bosenko) [4, p. 141].

It is necessary to tell some traces also about researches of scientists of the Kyiv school of achievements of foreign biological thought. As a rule, in Soviet times it was a criticism, exposing the shortcomings of Western research. It was noted that there is no single flow in Western biological science. This was facilitated by the sharp ideological struggle between metaphysics and dialectics, idealism and materialism. However, some achievements of foreign scientists were also noted. This mainly concerned those who defended materialist positions in biology. "Every year the camp of supporters of Michurin's biology grows, which is manifested in sympathy for the new point of view in biological form and speciation. Gradually, foreign scientists come to the conclusion that the development of species is dialectical» (N. Goncharenko) [4, p. 168].

Investigating the role of material models in biology, school scientists noted that more and more modern (at that time) biology began to use biological models as models, in particular viruses, extracellular life forms, which as a result of structural and functional specificity became models of microand macro levels of life. Thus, the transformation of a biological object into a model becomes, compared to its experimental research, the highest stage of development of science (N. Depenchuk) [5, p. 148]. Also, scientists of the school are actively studying the formation of the biological form of motion of matter, through the inclusion of it, in a transformed form, lower forms of motion of matter (for example, photosynthesis). The peculiarities of the interaction of bodies in a living system are considered and it is determined that the correct way to study the essence of life is to find out the dependence of the functional role of bodies on the form of their existence in the body, on their connection with protein. And the scale and form of development of each process depends on its significance in the biological form of motion of matter (O. Sudin) [6, p. 137].

Investigating the problem of "compilation" in philosophy and biology, school scientists draw attention to the fact that the penetration of physics into the world of "elementary» atomic particles and the process of studying life at the molecular and submolecular levels - mean the development of deeper structural levels of matter. Thus, one of the fundamental theoretical and cognitive problems comes to the fore, especially in the field of biology, the problem of construction (complementarity, mutual fusion) and the problem of isolation (mutual exclusion) of structural levels and the sciences about them. The emergence of new branches of biological science has led to changes in the position of all branches in the complex. The objective basis for determining trends in the future development of all sets of biological sciences and each separately is the need to penetrate our knowledge to the ever deeper structural levels of living things. The epoch of natural-scientific progress makes the cognitive penetration into the regularity of conditioning by lower (deepest) levels of higher ones more effective, therefore researches of biological at molecular and submolecular levels become especially perspective (P. Bobrovskyi) [7, p. 153-159].

In the scientific research of scientists of the Soviet period, attention should be paid to research that concerned the study in science and philosophy of concepts such as goals and purposeful attitude, which was used in three senses:

«1) as a specific cognitive technique, reasons;

2) as an objective relationship that is achieved through feedback, in which the goal is the result of the behavior of a functioning system, the end effect of which is the preservation of the original essential variables;

3) as an ideal image of the future result of the process generated by consciousness» [10, p. 117].

It can also find a justification for the fruitfulness of the concept of purpose in biology and attempts to reveal the logical and epistemological foundations of target techniques. The application of purpose in the first sense follows from the dialectic of cause and effect, analysis and synthesis, logical and historical. Thus, we can say that this technique, in fact, consists of three different techniques applied to different objects (O. Yatsenko) [10, p. 118].

Over the years, the field of scientific interest of scientists of the Kyiv School of Philosophy of Biology has expanded and the study of such concepts as "biological» and "social» has been added to the scope of their scientific research. In the course of these studies, it was found that these concepts reflect the specifics of systems that relate to qualitatively different forms of motion of matter. It was noted that they are legitimate to consider in relation to different levels of organization of biological and social systems, which may express different aspects, aspects, manifestations of only social systems, in particular the double determination of human life. Thus, for the organism as a whole and for supra-individual social systems, the dominant is the social, which "subdues» the biological to its laws, "humanizes» it. In the process of "humanization», socialization of the biological there is a complex interaction between them, the dialectical connection of natural and social (V. Chernyi) [15, p. 39].

However, an important aspect in the study of living matter, said Kyiv scientists, is the problem of its evolution, ie the process of self-complication, adaptation to the environment. Scientists have tried, from the point of view of cybernetics, to analyze the general mechanisms of evolution, to formulate the main driving contradiction of life, as a contradiction between the control algorithm of the control device of the biosystem and the information coming to it. The basic law of development of biosystems was considered by scientists as a process of building a hierarchy of control algorithms by their consistent display. Thus, the process of formation of the hierarchy of control algorithms by sequential mapping could be considered as the basic law of evolution of living matter (V. Velkov) [11, p. 63-67].

Investigating alternative and synthetic trends in the development of biology, Kyiv scientists noted that the immanent, intrinsic content of the progressive development of modern biological knowledge is the contradiction between traditional biology and 
new biology, which express the main directions in the science of living nature. This is explained by scientists that "theories of traditional biology and theories of new biology are mainly and essentially based on different structural levels of biological systems; their subject is, respectively, the laws of the macro level of living matter. I. Michurin's teaching was formed within the framework of traditional biology and, along with other scientific biological concepts, occupies a proper place» [13, p. 53]. At present, for the progress of biology, it is important to establish the correct relationship between the sciences that study living matter at different levels of its structural organization, guided by the principles of conformity and complementarity, which acquire general epistemological significance. This means that the data of molecular biology, genetics, studying organisms, processes at the elementary-molecular level, complement and enrich the scientific achievements of biology, which studies organisms and processes at the macromorphological level, and which in turn mutually enrich and complement molecular biology (V. Kolodyazhnyi) [13, p. 59].

Conclusion. Summing up, we would like to draw attention to the fact that modern trends in philosophical analysis, which are closely intertwined with the active penetration of the human dimension into epistemology and worldview are consistent with the appeal of the biological sciences to human and environmental problems, to environmental problems in a globalized world. Similar problems were raised by scientists of the Kyiv School of Philosophy of Biology in Soviet times, they searched for and transformed approaches that were reflected in research, research projects, and numerous publications. Thus, we can say that Kyiv scientists have made an important contribution to solving the problem of synthesis of biological knowledge, which today acquires great ideological and methodological significance; they contributed to the formation of a general system of views on living nature, and their study of various methods of cognition of living things, especially in biology and exact sciences, helped to maintain the focus of biological knowledge on the study of development problems. Successes in the study of the hierarchy of living things, the general principles of its organization, which were achieved with the development of genetics, molecular biology, cybernetics, ecology, gave rise to new directions of theoretical thought.

\section{References:}

1. Huberskyi L.V., Kremen V.H., Konverskyi A.E. ta in. (2020) Kyivska svitohliadno-hnoseolohichna shkola druhoi polovyny XX stolittia: monohrafiia [Kyiv worldview and epistemological school of the second half of the twentieth century]. Kyiv: VPZ «Kyivskyi universytet». (in Ukrainian)

2. Konverskyi A.E., Bychko I.V., Ohorodnyk I.V. (2005) Filosofska dumka u Kyivskomu universyteti: istoriia i suchasnist. [Philosophical Thought at Kyiv University: History and Modernity] / Za zah. red. prof. A. Konverskoho. Kyiv: Tsentr navchalnoi literatury. (in Ukrainian)

3. Kyivskyi derzhavnyi universytet (1964) Filosofski problemy suchasnoho pryrodoznavstva [Problems of modern science]. Mizhvidomchyi naukovyi zbirnyk. Kyiv: Vydavnytstvo Kyivskoho universytetu. Vypusk 1.

4. Kyivskyi derzhavnyi universytet (1964) Filosofski problemy suchasnoho pryrodoznavstva [Problems of modern science]. Mizhvidomchyi naukovyi zbirnyk. Kyiv: Vydavnytstvo Kyivskoho universytetu. Vypusk 2.

5. Kyivskyi derzhavnyi universytet (1965) Filosofski problemy suchasnoho pryrodoznavstva [Problems of modern science]. Mizhvidomchyi naukovyi zbirnyk. Kyiv: Vydavnytstvo Kyivskoho universytetu. Vypusk 3.

6. Kyivskyi derzhavnyi universytet (1965) Filosofski problemy suchasnoho pryrodoznavstva [Problems of modern science]. Mizhvidomchyi naukovyi zbirnyk. Kyiv: Vydavnytstvo Kyivskoho universytetu. Vypusk 4.

7. Kyivskyi derzhavnyi universytet (1966) Filosofski problemy suchasnoho pryrodoznavstva [Problems of modern science]. Mizhvidomchyi naukovyi zbirnyk. Kyiv: Vydavnytstvo Kyivskoho universytetu. Vypusk 5.

8. Kyivskyi derzhavnyi universytet (1967) Filosofski problemy suchasnoho pryrodoznavstva [Problems of modern science]. Mizhvidomchyi naukovyi zbirnyk. Kyiv: Vydavnytstvo Kyivskoho universytetu. Vypusk 8.

9. Kyivskyi derzhavnyi universytet (1968) Filosofski problemy suchasnoho pryrodoznavstva [Problems of modern science]. Mizhvidomchyi naukovyi zbirnyk. Kyiv: Vydavnytstvo Kyivskoho universytetu. Vypusk 12.

10. Kyivskyi derzhavnyi universytet (1969) Filosofski problemy suchasnoho pryrodoznavstva [Problems of modern science]. Mizhvidomchyi naukovyi zbirnyk. Kyiv: Vydavnytstvo Kyivskoho universytetu. Vypusk 15.

11. Kyivskyi derzhavnyi universytet (1971) Filosofski problemy suchasnoho pryrodoznavstva [Problems of modern science]. Mizhvidomchyi naukovyi zbirnyk. Kyiv: Vydavnytstvo Kyivskoho universytetu. Vypusk 23.

12. Kyivskyi derzhavnyi universytet (1972) Filosofski problemy suchasnoho pryrodoznavstva [Problems of modern science]. Mizhvidomchyi naukovyi zbirnyk. Kyiv: Vydavnytstvo Kyivskoho universytetu. Vypusk 27.

13. Kyivskyi derzhavnyi universytet (1972) Filosofski problemy suchasnoho pryrodoznavstva [Problems of modern science]. Mizhvidomchyi naukovyi zbirnyk. Kyiv: Vydavnytstvo Kyivskoho universytetu. Vypusk 29.

14. Kyivskyi derzhavnyi universytet (1974) Filosofski problemy suchasnoho pryrodoznavstva [Problems of modern science]. Mizhvidomchyi naukovyi zbirnyk. Kyiv: Vydavnyche obiednannia «Vyshcha shkola». Vydavnytstvo pry Kyivskomu derzhavnomu universyteti. Vypusk 35.

15. Kyivskyi derzhavnyi universytet (1976) Filosofski problemy suchasnoho pryrodoznavstva [Problems of modern science]. Mizhvidomchyi naukovyi zbirnyk. Kyiv: Vydavnyche obiednannia "Vyshcha shkola». Vydavnytstvo pry Kyivskomu derzhavnomu universyteti. Vypusk 41.

\section{Список літератури:}

1. Губерський Л.В., Конверський А.С. та ін. Київська світоглядно-гносеологічна школа другої половини : монографрія. Київ : ВПЦ «Київський університет», 2020. 240 с.

2. Конверський А.Є., Бичко I.В., Огородник І.В. Філософська думка у Київському університеті: історія і сучасність / За заг. ред. проф. А.С. Конверського. Київ : Центр навчальної літератури, 2005. 336 с.

3. Філософські проблеми сучасного природознавства. Міжвідомчий науковий збірник. Київ : Видавництво Київського університету, 1964. Вип. 1.

4. Філософські проблеми сучасного природознавства. Міжвідомчий науковий збірник. Київ : Видавництво Київського університету, 1964. Вип. 2. 
5. Філософоскі проблеми сучасного природознавства. Міжвідомчий науковий збірник. Київ : Видавництво Київського університету, 1965. Вип. 3.

6. Філософські проблеми сучасного природознавства. Міжвідомчий науковий збірник. Київ : Видавництво Київського університету, 1965. Вип. 4.

7. Філософські проблеми сучасного природознавства. Міжвідомчий науковий збірник. Київ : Видавництво Київського університету, 1966. Вип. 5.

8. Філософські проблеми сучасного природознавства. Міжвідомчий науковий збірник. Київ : Видавництво Київського університету, 1967. Вип. 8.

9. Філософські проблеми сучасного природознавства. Міжвідомчий науковий збірник. Київ : Видавництво Київського університету, 1968. Вип. 12.

10. Філософські проблеми сучасного природознавства. Міжвідомчий науковий збірник. Київ : Видавництво Київського університету, 1969. Вип. 15.

11. Філософські проблеми сучасного природознавства. Міжвідомчий науковий збірник. Київ : Видавництво Київського університету, 1971. Вип. 23.

12. Філософські проблеми сучасного природознавства. Міжвідомчий науковий збірник. Київ : Видавництво Київського університету, 1972. Вип. 27.

13. Філософрькі проблеми сучасного природознавства. Міжвідомчий науковий збірник. Київ : Видавництво Київського університету, 1972. Вип. 29.

14. Філософські проблеми сучасного природознавства. Міжвідомчий науковий збірник. Київ : Видавниче об’еднання «Вища школа». Вид-во при Київському державному університеті. 1974. Вип. 35.

15. Філософські проблеми сучасного природознавства. Міжвідомчий науковий збірник. Київ : Видавниче об’еднання «Вища школа». Вид-во при Київському державному університеті. 1976. Вип. 41. 